\title{
Review Article \\ Low Reactive Level Laser Therapy for Mesenchymal Stromal Cells Therapies
}

\author{
Toshihiro Kushibiki, Takeshi Hirasawa, Shinpei Okawa, and Miya Ishihara \\ Department of Medical Engineering, National Defense Medical College, 3-2 Namiki, Tokorozawa, Saitama 359-8513, Japan \\ Correspondence should be addressed to Toshihiro Kushibiki; toshi@ndmc.ac.jp
}

Received 19 September 2014; Accepted 14 March 2015

Academic Editor: Mark F. Pittenger

Copyright (C) 2015 Toshihiro Kushibiki et al. This is an open access article distributed under the Creative Commons Attribution License, which permits unrestricted use, distribution, and reproduction in any medium, provided the original work is properly cited.

\begin{abstract}
Low reactive level laser therapy (LLLT) is mainly focused on the activation of intracellular or extracellular chromophore and the initiation of cellular signaling by using low power lasers. Over the past forty years, it was realized that the laser therapy had the potential to improve wound healing and reduce pain and inflammation. In recent years, the term LLLT has become widely recognized in the field of regenerative medicine. In this review, we will describe the mechanisms of action of LLLT at a cellular level and introduce the application to mesenchymal stem cells and mesenchymal stromal cells (MSCs) therapies. Finally, our recent research results that LLLT enhanced the MSCs differentiation to osteoblast will also be described.
\end{abstract}

\section{Introduction}

Mesenchymal stromal cells (MSCs) are the promising source for the regenerative medicine and repair of various tissues in the treatment of a range of diseases. The differentiation of these cells to different lineages is dictated by the local extracellular matrix (ECM) as well as spatial and temporal cues, including growth factors and cell-cell interactions. In bone formation, mechanotransduction and physical cues, such as shear stress and fluid flow [1], also influence the differentiation of MSCs. However, the fundamental questions that how to control the differentiation of MSCs to matured cells must be answered. In particular, a better understanding of how specific factor may alter the fate of differentiation of MSCs is needed. Their rapid and selective differentiation should provide the potential of new therapeutic approaches for the restoration of damaged or diseased tissue. We have reported that the laser irradiation to MSCs influences cell differentiation and possible mechanisms of cells differentiation by laser were proposed [2-4]. In this review, we will describe the mechanisms of action of laser irradiation and introduce the application to MSCs therapies including our research results.

A laser (light amplification by stimulated emission of radiation) is a device that generates electromagnetic radiation that is relatively uniform in wavelength, phase, and polarization. This technology was originally described by Maiman in 1960 in the form of a ruby laser [5]. The properties of lasers have allowed for numerous medical applications, including their use in surgery, activation of photodynamic agents, and various ablative therapies in cosmetics, all of which are based on heat generated by the laser beam, in some cases leading to tissue destruction [6-13]. Low reactive level laser therapy (LLLT) is a form of medical treatment in which human tissue is irradiated with a low-powered laser (on the order of several hundred milliwatts) to induce therapeutic changes. In an attempt to explore the carcinogenic potential of laser light, Mester et al. in 1967 applied a low-powered ruby laser with a $694 \mathrm{~nm}$ wavelength to the shaved dorsal skin of mice [14]. Contrary to their expectations, the laser irradiation did not cause cancer but instead improved hair growth. As the first study to document the biological effect of lasers, their findings became a springboard for subsequent LLLT research. Although light-based therapies had been used for a long time and ultraviolet therapy has a history longer than a century [15], the work of Mester et al. was significant in demonstrating the effects of laser light, which has the unique characteristics of monochromaticity and coherence. Following subsequent experiments, Mester and colleagues reported in 1971 that low power laser rays accelerated wound healing [16]. Since those 
early days, numerous in vitro and in vivo studies of LLLT in the context of regenerative medicine have demonstrated a wide variety of therapeutic effects including improvements in wound healing, collagen synthesis, cell proliferation, fracture repair, and local blood circulation, as well as suppression of inflammation and pain. According to da Silva et al. [17], the types of laser most frequently used for wound healing and tissue repair are helium-neon (He- $\mathrm{Ne}$ ) lasers and diode lasers, including gallium-aluminum-arsenic (Ga-Al-As), arsenicgallium (As-Ga), and indium-gallium-aluminum-phosphide (In-Ga-Al-P) lasers.

A large number of literatures and review articles [1820] have shown that LLLT accelerates wound healing, and we present some typical results here. Irradiation of cultured human keratinocytes with a $632 \mathrm{~nm}$ heliumneon laser elevated the interleukin- $1 \alpha$ and interleukin-8 mRNA levels, promoted keratinocyte migration and proliferation, and accelerated wound repair [21]. In addition, in vitro studies of laser-irradiated cells revealed elevated levels of vascular endothelial growth factor (VEGF) [22] and transforming growth factor $\beta$ (TGF $\beta$ ) expression [23]. These findings illustrate the laser-enhanced expression of many cytokines and growth factors in keratinocytes and fibroblasts, the key cellular mediators of the wound-healing process. In addition, after mice with lipopolysaccharideinduced peritonitis were irradiated with a $904 \mathrm{~nm}$ gallium arsenide (Ga-As) laser, inflammatory cell migration was inhibited [24]. In a rat model of carrageenan-induced pleuritis, a $660 \mathrm{~nm}$ In-Ga-Al-P laser suppressed the production of inflammatory cytokines and the migration of inflammatory cells [25]. A group of researchers led by Albertini are actively pursuing research on LLLT's anti-inflammatory effects [2646]. In the field of regenerative medicine, LLLT accelerates osteoblast proliferation, bone formation [47], and bone repair [48]. Various groups have suggested the involvement of insulin-like growth factor-1 (IGF-1) [49], mitogen-activated protein kinase (MAPK)/extracellular signal-regulated kinase (ERK) [50], and bone morphogenetic protein (BMP)/Smad signaling cascades [51]. In addition, LLLT confers physiological effects to regeneration of damaged neurons [5255], articular cartilage [56], and muscle tissue [57-59]. To date, several mechanisms of biological action have been proposed, although none have been clearly established. These include augmentation of cellular ATP levels [60-62]; manipulation of inducible nitric oxide synthase (iNOS) activity [6367]; suppression of inflammatory cytokines such as tumor necrosis factor- (TNF-) $\alpha[61,68-70]$, interleukin- (IL-) $1 \beta[27,70,71]$, IL-6 [25, 70, 72-74], and IL-8 [25, 70, 72, 75]; upregulation of growth factors such as PDGF, IGF-1, NGF, and FGF-2 [71, 76-78]; alteration of mitochondrial membrane potential [79-82] due to chromophores found in the mitochondrial respiratory chain [83-85]; stimulation of protein kinase C (PKC) activation [86]; manipulation of nuclear factor- (NF-) $\kappa$ B activation [28]; induction of reactive oxygen species (ROS) $[87,88]$; modification of extracellular matrix components [89]; inhibition of apoptosis [79]; stimulation of mast cell degranulation [90]; and upregulation of heat shock proteins [91].
In the following paragraphs, we will discuss the cellular effects of LLLT that underlie its biological actions. Through our research, we have discovered (i) the presence of intracellular photoreceptors and physiological changes resulting from photoreception, (ii) postirradiation modifications in cellular signal transduction cascades, and (iii) postirradiation alterations in gene expression. These various effects do not occur in an isolated manner. Here, we will focus on how these effects interact with each other to induce modifications in cellular functions. We will also summarize typical results of the LLLT application to MSCs therapies.

\section{Laser-Induced Cellular Responses}

In order to elucidate the biological mechanisms underlying effects of low power lasers documented in experimental and clinical studies, one must consider the cellular responses to laser irradiation. The photons must be absorbed by electronic absorption bands belonging to some molecular chromophores or photoreceptors [92]. A chromophore or photoreceptor is a molecule (or part of a molecule) where the energy difference between electrons in two different molecular orbitals falls within the energy possessed by photons in the visible spectrum. In this section, we describe the intracellular photoreceptors and the cellular responses to laser light. One of the most distinctive features of LLLT relative to other modalities is that the effects are mediated not through induction of thermal effects but rather through a process called "photobiostimulation."

2.1. Intracellular Photoreceptor. In photobiology, photoreception refers to the intracellular process whereby wavelengthspecific photoreceptors absorb photon energy [92]. Photoreceptors are biomolecules that are capable of absorbing photoenergy, either intrinsically or via a molecular component. The mitochondrial respiratory chain includes multiple photoreceptors, as described below.

2.1.1. Cytochrome c Oxidase. The enzyme cytochrome $c$ oxidase receives electrons from respiratory-chain substrates via the cytochrome pathway and transfers them to oxygen molecules. Cytochrome $c$ oxidase has been proposed as the endogenous photoreceptor in the visible to near-infrared region (above $600 \mathrm{~nm}$ ) [93]. Scientists have conducted extensive research on the photobiomodulation by cytochrome $c$ oxidase, particularly in neuronal cells. In a study of neurons functionally inactivated by tetrodotoxin, a voltagedependent sodium channel blocker [94], near-infrared irradiation restored the activity of intoxicated cytochrome $c$ oxidase by altering its redox state. In another study, laser irradiation of mitochondria increased cytochrome $c$ oxidase activity, polarographically measured levels of oxygen uptake, and subsequent ATP production [95]. Many other in vitro and in vivo studies of laser-induced cell growth have reported changes in cytochrome $c$ oxidase activity and ATP production following irradiation [81, 96-103]. 
2.1.2. Porphyrin. Porphyrins are a group of macrocyclic organic compounds that contain four pyrrole subunits joined by methine bridges. These mostly green- or redcolored compounds have specific absorption spectra and emit red fluorescence. Naturally occurring porphyrins, including those found in the human body, often form complexes with an iron or magnesium ion coordinated to the four pyrrole nitrogen atoms. For example, iron protoporphyrin IX (PPIX) complexes (i.e., heme $b$ ) form the prosthetic groups of hemoglobin, catalase, and peroxidase. Mitochondrial cytochromes also contain iron-porphyrin groups (nonheme b). The PPIX absorption spectrum has five major peaks in the range of 400 to $650 \mathrm{~nm}$, with peak height decreasing as the absorption wavelength increases. The excited triplet state of PPIX, formed by absorption of laser photons, generates ROS by transferring energy to ground-state oxygen atoms. A mode of photodynamic therapy (PDT) that exploits this feature has been developed for anticancer treatment. In this technique, patients are administered PPIX or its precursor, 5aminolevulinic acid (ALA), and ROS are generated with local laser irradiation to kill malignant cells or epithelial cells of vascular neoplasms [104].

2.1.3. Flavoproteins (Flavin Proteins). Flavoproteins are a group of protein complexes containing a riboflavin prosthetic group (e.g., flavin adenine dinucleotide [FAD] or flavin mononucleotide [FMN]). Most flavoproteins function as flavin enzymes, which use iron, molybdenum, copper, manganese, and other heavy metal ions as cofactors. These proteins have major absorption peaks in the range of 350 to $500 \mathrm{~nm}$. Flavoproteins mediate a wide array of biological processes, such as bioluminescence, quenching of oxidative stress-induced radicals, DNA repair, and apoptosis [105]. Some researchers, including the present author, have reported the roles of flavoproteins as intracellular photoacceptors $[2,3$, 106].

2.1.4. Other Groups of Photoreceptors. In addition to the three major groups of photoreceptors explained above, there are other types of photoreceptors, including rhodopsin, bilirubin, melanin, pterin, vitamin $\mathrm{B} 6$, vitamin $\mathrm{K}$, nicotinamide adenine dinucleotide (phosphate) hydrogen $[\mathrm{NAD}(\mathrm{P}) \mathrm{H}]$, urocanic acid, and tryptophan.

2.2. Laser-Induced Changes in Signaling Cascades. It is clear that signal transduction pathways regulate cells in order to transduce the signal from the cellular photoreceptors that absorb photon energy to the biochemical machinery that controls gene transcription. Many researchers believe that the photon energy captured by intracellular receptors leads to alterations in gene and protein expression via a series of processes that modify signaling cascades. However, little is known regarding how light-stimulated receptors transduce their signals to the nucleus, or how these signals mediate the expression of particular genes. We have studied the mechanisms underlying the promotion and suppression of stem cell differentiation, with a focus on FAD-containing cryptochromes as cellular photoreceptors [2,3]. Our research suggested that light-activated cryptochromes migrate into the nucleus, where they regulate the expression of proteins located downstream of the E-boxsequence. As a matter of course, cell functions are regulated by an array of other factors, including ROS. Therefore, we will now describe the biochemical changes LLLT induces beyond the photoreceptor absorption of light energy, as reported in the literature.

2.2.1. Redox Pathways. Several oxygen and nitrogen radicals have been proposed to transduce mitochondrial signals to the nucleus. Those species react with NAD, NADH, NADP, $\mathrm{NADPH}$, glutathione, glutathione sulfide, thioredoxin, and thioredoxin sulfide [107]. The cell contains several endogenous sensors for these species (typically, superoxide dismutase [SOD]) [108]. Upon detection of ROS, the cell activates self-defense pathways by altering its gene expression patterns [109]. If these self-defense mechanisms fail, the cell will undergo apoptosis. The levels of ROS strictly determine the expression of proteins regulating cell proliferation, suggesting that oxygen radicals act as second messengers [110, 111]. ROS are considered to play key roles in the control of cellular functions [112]. Low power laser beams with wavelengths around $630 \mathrm{~nm}$ generate oxygen radicals in exposed cells $[113,114]$. We have also discovered significant increases in the levels of oxygen radicals in cells exposed to laser light (wavelength: $405 \mathrm{~nm}$ ) [87]. Although the specific mechanism remains unknown, laser-induced intracellular generation of ROS probably involves energy transfer from PPIX and other photoreceptors present in the cell. In addition, several groups have described cellular functions mediated by nitric oxide (NO), which is upregulated by laser irradiation, as well as by inducible nitric oxide synthase (iNOS) $[65,67,114-116]$. The mechanism of laser-induced control of cellular functions is believed to hinge on the regulation of photoreceptor activity and the intracellular levels of ROS.

2.2.2. Transcription Factors. Several researchers have reported that the aforementioned redox pathways trigger changes in the expression of many transcription factors. Here, we briefly describe one of the best-characterized transcription factors in the LLLT field, NF- $\kappa \mathrm{B}[117,118]$. Published articles on other transcription factors mediating a multitude of cell functions have made it clear that their expression levels are also modified upon exposure to laser irradiation. As a transcription factor, NF- $\kappa$ B can simultaneously induce the expression of IL-1, IL-2, IL-6, IL-8, IL-12, TNF- $\alpha$, and other proinflammatory cytokines. It also controls the expression of apoptosis-related proteins, which play a critical role in tumor cell growth and immortalization. Several studies have shown that the aforementioned redox pathways trigger increases in NF- $\kappa \mathrm{B}$ levels $[117,118]$. This mechanism is considered to account, at least in part, for the observation that low power laser irradiation induces the expression of various cytokines. Rizzi et al. have showed that histological abnormalities with increase in collagen concentration and oxidative stress were observed after trauma. The associated reduction of inducible nitric oxide synthase overexpression and collagen production suggest 
that the NF- $\kappa \mathrm{B}$ pathway is a signaling route involved in the pathogenesis of muscle trauma [118]. The hypoxia-inducible factor (HIF-1) is also a ubiquitous transcription factor involved in the control of cell and tissue responses to hypoxia, specifically in angiogenesis, hematopoiesis, and anaerobic energy metabolism. There are over 70 genes which have been established as direct targets by identification of critical HIF-1 binding sites [119]. In addition, the activator protein(AP-) 1 is involved in cellular proliferation, transformation, and death [120]. AP-1 is not a single protein but a complex array of heterodimers composed of proteins that belong to the Jun, Fos, and ATF subfamilies, which recognize specific nuclear target sequences. Different dimeric combinations can stimulate a variety of gene expression patterns. AP-1 can be activated by growth factors, cytokines, hypoxia, ionizing, and UV radiation $[121,122]$.

2.2.3. Circadian Rhythm. The circadian rhythm, a roughly 24-hour cycle of cellular events, was acquired during the early stages of evolution and is ubiquitous from unicellular organisms to mammals. Several mammalian clock genes work together to establish a stable oscillation of approximately 24 hours. Circadian clock proteins, such as brainmuscle Arnt-like protein 2 (BMAL2), clock, cryptochrome (CRY), and period (PER), set the pace of the clock in almost all cell types (e.g., the timing of cell division and other cellular activities). CRY, a blue-light receptor in higher plants and Drosophilidae [123], utilizes as its chromophore the FAD coenzyme, which undergoes blue-light excitation. This observation led to the idea that light-excited FAD transfers electrons to a certain substrate. However, the validity of this theory has not been tested. Bone metabolism (remodeling) is a continuous homeostatic process involving resorption of existing bone by osteoclasts and formation of new bone by osteoblasts. Fu et al. showed that circadian rhythms mediate bone formation [124], and Kawasaki et al. reported that the E-box motif, a circadian regulatory sequence, is involved in the osteoblast expression of bone morphogenetic protein(BMP-) 4 [125]; these findings indicate that CRY proteins regulate various homeostatic and physiological events via Ebox elements. We conducted research on the effects of lasers on endocellular distribution and expression of CRY using laser beams (wavelength: $405 \mathrm{~nm}$ ), which correspond to the absorption band of the CRY coenzyme FAD [2]. We will describe the results below.

\section{LLLT for MSCs Therapies}

Since LLLT has been scientifically proven as a beneficial therapeutic modality for numerous diseases and diseased conditions, it was applied to enhance MSCs proliferation and differentiation. The recent 3-year reports regarding LLLT application to increase MSCs proliferative and differentiation potential were summarized in Table 1 [126-135, 138-143]. Abrahamse's group published some literatures for LLLT application to stem cells. It is the cellular effect of increasing proliferation and viability that may significantly contribute to the addition of LLLT to the many biomedical disciplines that further augment the successes of regenerative medicine [144]. They reported that low power laser irradiation has been shown to induce adipose-derived stem cell activity by increasing migration, proliferation, and viability, activating protein expression and inducing differentiation in progenitor cells [145-147]. Wu et al. reported that LLLT suppresses inflammatory response of human adipose-derived stem cells by modulating intracellular cyclic AMP level and NF- $\kappa \mathrm{B}$ activity [129]. Lipopolysaccharide- (LPS-) induced proinflammatory cytokine expression was inhibited by LLLT and the intracellular cAMP level, which acts to downregulate $\mathrm{NF}-\kappa \mathrm{B}$ transcriptional activity which was increased. Those results indicate that LLLT can potentially be applied in antiinflammatory therapy followed by stem cell therapy. We reported that the laser irradiation can direct the extracellular calcification of primary MSCs by altering the intracellular localization of the circadian rhythm protein, CRY1 [2, 3]. Figure 1 presents the beam profile of the laser (wavelength: $405 \mathrm{~nm}$ ) used in the study (Panel (a)) and the changes in mouse bone marrow mesenchymal stromal cells irradiated for 3 minutes and then cultured for 14 days in osteoblast differentiation medium (Panel (b)) [3]. Alizarin red staining revealed that the stained cells were distributed in a circular area with a diameter similar to that of the laser beam. In addition, the results of immunostaining for CRY1 protein are represented in Figure 2. Whereas CRY1 was distributed across the cytoplasm in control cells, it was localized to the nucleus in cells exposed to laser (wavelength: $405 \mathrm{~nm}$ ) irradiation. The timing of nuclear accumulation of clock proteins constitutes an important step in the transcription-translation feedback loop driving the circadian core oscillator and is controlled by regulating protein localization and turnover. Our results show that these laser beams promote the nuclear localization of CRY1 and mediate the expression of CRY1 and other proteins downstream of the E-box, which played a critical role in deciding the expression of BMPs [3]. We also reported that laser irradiation suppressed the adipocyte differentiation of mesenchymal stromal cells [2] and accelerated their differentiation into chondrocytes [4]. Abramovitch-Gottlib et al. reported that the consequent phenotype modulation and development of MSCs towards ossified tissue were studied in the combined 3D biomatrix/LLLT system [148]. Their results obtained from the irradiated samples showed enhanced tissue formation, appearance of phosphorous peaks, and calcium and phosphate incorporation to newly formed tissue. Moreover, in irradiated samples ALP activity was significantly enhanced in early stages and notably reduced in late stages of culturing. Those findings of cell and tissue parameters up to 28 days of culture revealed higher ossification levels in irradiated samples compared with the control group. They suggested that both the surface properties of the 3D crystalline biomatrices and the LLLT have biostimulatory effect on the conversion of MSCs into bone-forming cells and on the induction of ex vivo ossification [148]. In addition, lasers in visible wavelength were used mostly for LLLT, but the novel laser sources, such as terahertz $(\mathrm{THz})$ laser, were recently investigated for MSCs therapy [135-137]. Alexandrov et al. reported that extended exposure to broad-spectrum $\mathrm{THz}$ 
TABLE 1: The effect of LLLT on the MSCs proliferation and differentiation (literatures published in recent 3 years).

\begin{tabular}{|c|c|c|}
\hline Authors & Brief description & Reference \\
\hline Park et al. & $\begin{array}{l}\text { LLLT enhanced angiogenic effect of adipose-derived stromal cells (ASCs) spheroid in hind } \\
\text { limb ischemia mice. LLLT is an effective biostimulator of spheroid ASCs in tissue } \\
\text { regeneration that enhanced the survival of ASCs and stimulated the secretion of growth } \\
\text { factors in the ischemic hind limb. }\end{array}$ & {$[126]$} \\
\hline Farfara et al. & $\begin{array}{l}\text { MSCs were stimulated by LLLT in order to affect neurological behavior and beta-amyloid } \\
\text { burden in progressive stages of Alzheimer's disease mouse model. }\end{array}$ & [127] \\
\hline Yang et al. & $\begin{array}{l}\text { LLLT was applied as an adjunct therapy for MSCs transplantation on the functional } \\
\text { recovery of crushed sciatic nerve in rats. }\end{array}$ & [128] \\
\hline Wu et al. & $\begin{array}{l}\text { LLLT increased the intracellular level of cAMP, which acts to downregulate NF- } \kappa \mathrm{B} \\
\text { transcriptional activity. }\end{array}$ & [129] \\
\hline Nagata et al. & $\begin{array}{l}\text { The combination of bone marrow aspirate/LLLT yielded significantly greater bone } \\
\text { formation in surgically created critical-size defects in rat calvaria. }\end{array}$ & {$[130]$} \\
\hline Manuguerra-Gagné et al. & $\begin{array}{l}\text { A laser-induced model of open angle glaucoma (OAG) was used to evaluate the potential of } \\
\text { bone marrow cell populations and the mechanisms involved in tissue repair. Laser-induced } \\
\text { tissue remodeling as a method of targeting effector cells into damaged tissues was also } \\
\text { evaluated. }\end{array}$ & {$[131]$} \\
\hline Lipovsky et al. & $\begin{array}{l}\text { The ability of broadband visible light illumination to promote proliferation of MSCs was } \\
\text { evaluated. }\end{array}$ & {$[132]$} \\
\hline Giannelli et al. & $\begin{array}{l}\text { The effects of LLLT on mouse MSCs proliferation were investigated underlying cellular and } \\
\text { molecular mechanisms, focusing the attention on the effects of laser irradiation on Notch-1 } \\
\text { signal activation and membrane ion channel modulation. }\end{array}$ & {$[133]$} \\
\hline Choi et al. & $\begin{array}{l}\text { Adipose-derived mesenchymal stem cells- (ASCs-) seeded acellular dermal matrix was used } \\
\text { with LLLT to repair bone defect. }\end{array}$ & {$[134]$} \\
\hline Alexandrov et al. & $\begin{array}{l}\text { Terahertz (THz) laser irradiation of MSCs can cause specific catalytic changes in cellular } \\
\text { function that are closely related to the gene expression and differentiation state. }\end{array}$ & {$[135-137]$} \\
\hline Wu et al. & $\begin{array}{l}\text { The change in mRNA expression in rat MSCs after LLLT and the associated molecular } \\
\text { mechanisms were investigated. }\end{array}$ & {$[138]$} \\
\hline Wu et al. & $\begin{array}{l}\text { LLLT induced IGF1 expression to promote both the proliferation and osteogenic } \\
\text { differentiation of MSCs, whereas it may induce BMP2 expression primarily to enhance } \\
\text { osteogenic differentiation. }\end{array}$ & {$[139]$} \\
\hline Wang et al. & $\begin{array}{l}\text { MicroRNA-193 proproliferation effects for bone MSCs were revealed after LLLT through } \\
\text { inhibitor of growth family, member } 5 .\end{array}$ & {$[140]$} \\
\hline Soleimani et al. & $\begin{array}{l}\text { The influence of LLLT at different energy densities on MSCs differentiation into neuron and } \\
\text { osteoblast was examined. }\end{array}$ & {$[141]$} \\
\hline Saygun et al. & $\begin{array}{l}\text { LLLT increased the proliferation of osteoblast cells and stimulated the release of bFGF, } \\
\text { IGF-1, and IGFBP3 from these cells. }\end{array}$ & {$[142]$} \\
\hline
\end{tabular}

radiation results in specific changes in the functionality of cellular DNA. Certain genes in irradiated MSCs cultures are activated, while other genes are repressed. Many of the MSCs genes do not respond to the selected radiation conditions at all, showing that the effect is specific. Additionally, 9 hours of exposure causes significant changes in the MSCs gene expression, while the response to shorter duration (2 and 4 hours) is appreciably less pronounced. Hence, they discussed that the effect of $\mathrm{THz}$ radiation was gene and exposure specific and most likely is at the level of DNA transcription [137]. Although each researcher used a different type of laser (i.e., wavelength, power, and pulse-width), MSCs proliferative and differentiation potential can be increased. The mechanisms involved remain to be clarified, but LLLT is a valid approach for the preconditioning of MSCs in vitro prior cell transplantation.

\section{Conclusion}

Regenerative medicine and stem cell therapy have the potential to provide diseases-free, functional tissues and organs, improving the quality of life for patients. They have also the ability to transform the treatment of human disease by introducing combined innovative new therapies such as stem cell therapies and LLLT. Today, researchers are conducting intensive basic and clinical research in the area of laser medicine and photobiology, with the goal of developing new diagnostic and therapeutic modalities. Here, we described some of the latest advances in research on the cellular effects of irradiation with lasers to MSCs. The biological mechanisms underlying such responses significantly differ by the type of laser, target of cells, and other experimental conditions. With the appropriate use of LLLT, 

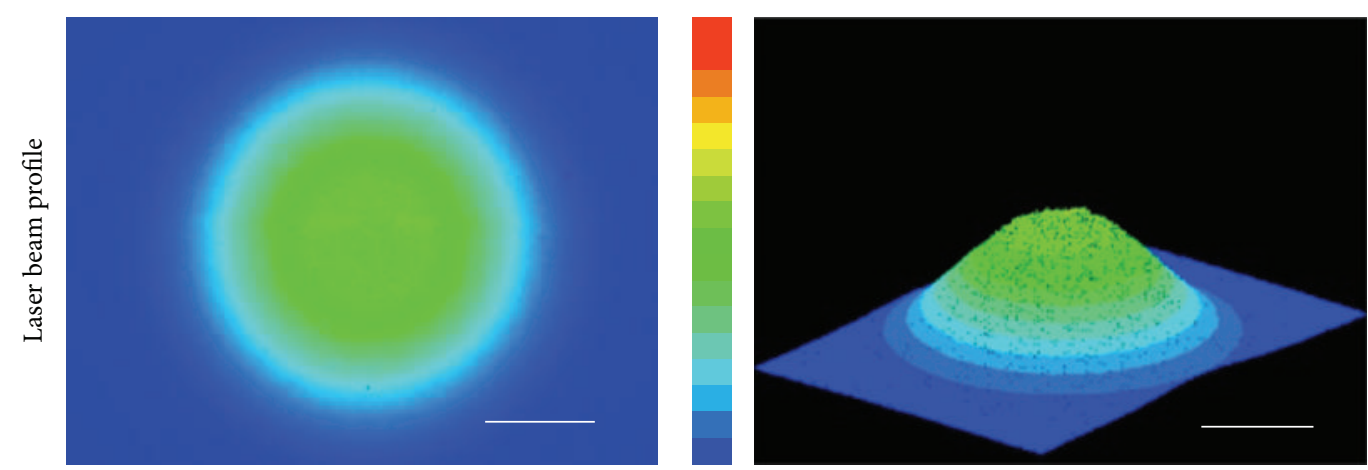

(a)

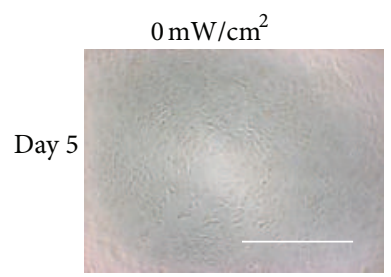

$50 \mathrm{~mW} / \mathrm{cm}^{2}$

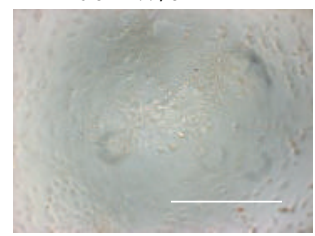

$100 \mathrm{~mW} / \mathrm{cm}^{2}$
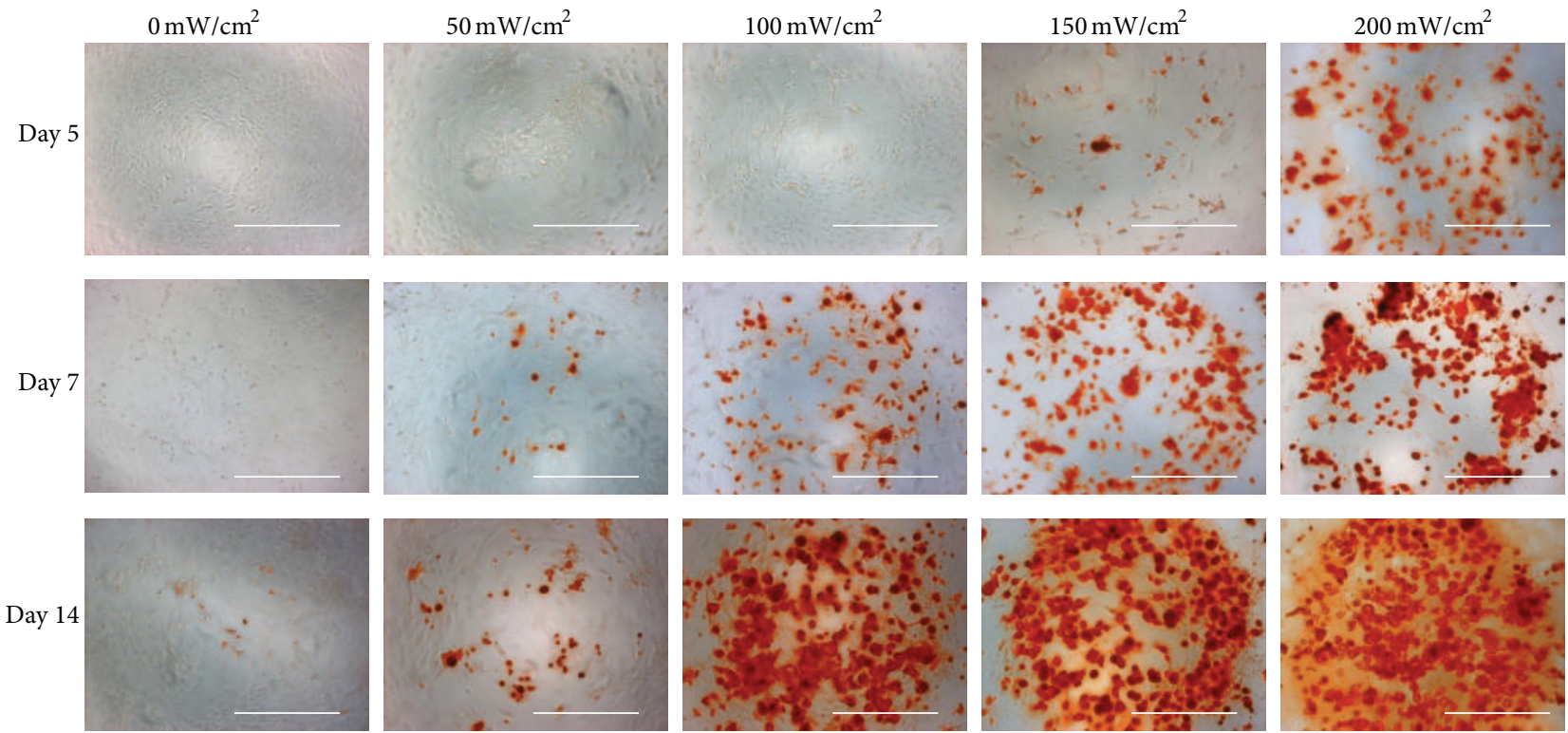

(b)

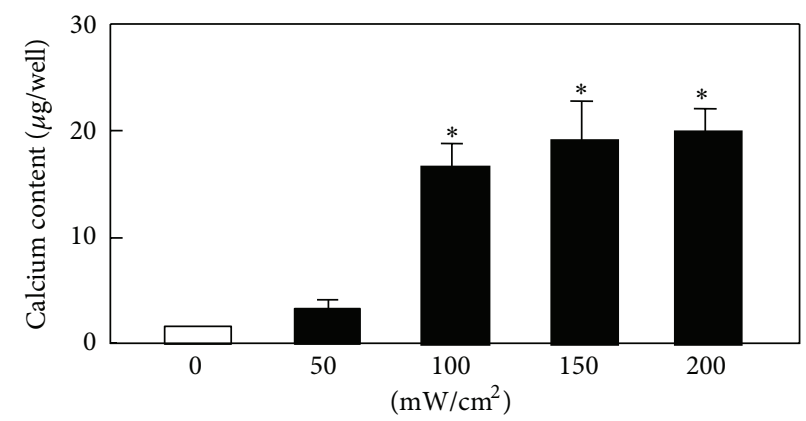

(c)

Figure 1: (a) The beam profile of the blue laser (wavelength: $405 \mathrm{~nm}$ ) used in this study (scale bars: $200 \mu \mathrm{m}$ ). MSCs were irradiated for 180 sec at various laser power levels. (b) Alizarin red S staining of irradiated MSCs (magnification 50x; scale bars: $400 \mu \mathrm{m}$ ). After laser irradiation, calcium deposition had increased around the cells in a dose-dependent manner. (c) The quantitative calcium content increased after blue laser irradiation (day 14) relative to nonirradiated cells. Calcium content increases varied with laser energy level $\left({ }^{*} P<0.01\right.$, indicating significant difference between the calcium content of laser-irradiated MSCs and controls) [3].

the proliferation rate of cultured cells, including MSCs, can be increased, which would be very useful in tissue engineering and regenerative medicine. We must accumulate a systematic knowledge base by carefully analyzing the experimental data currently available, as well as data collected in the future. We believe that light-based biomedical research will open new horizons for photodiagnosis, phototherapy, and MSCs therapies. 


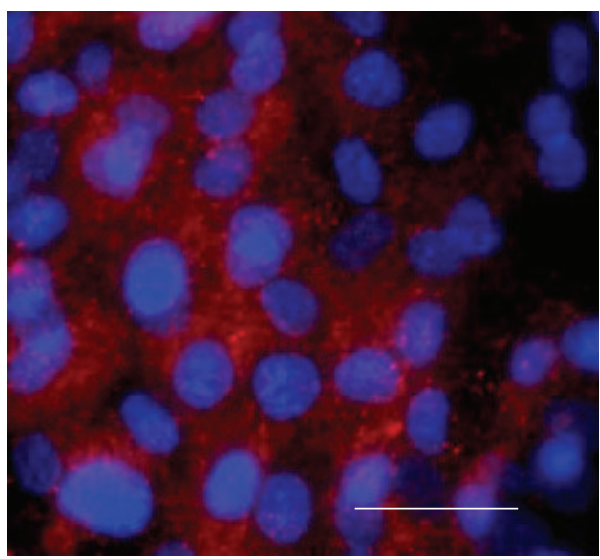

(A)

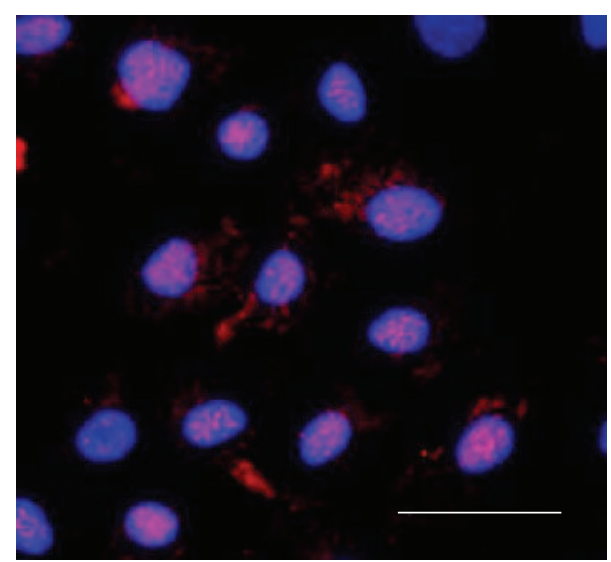

(B)

(a)

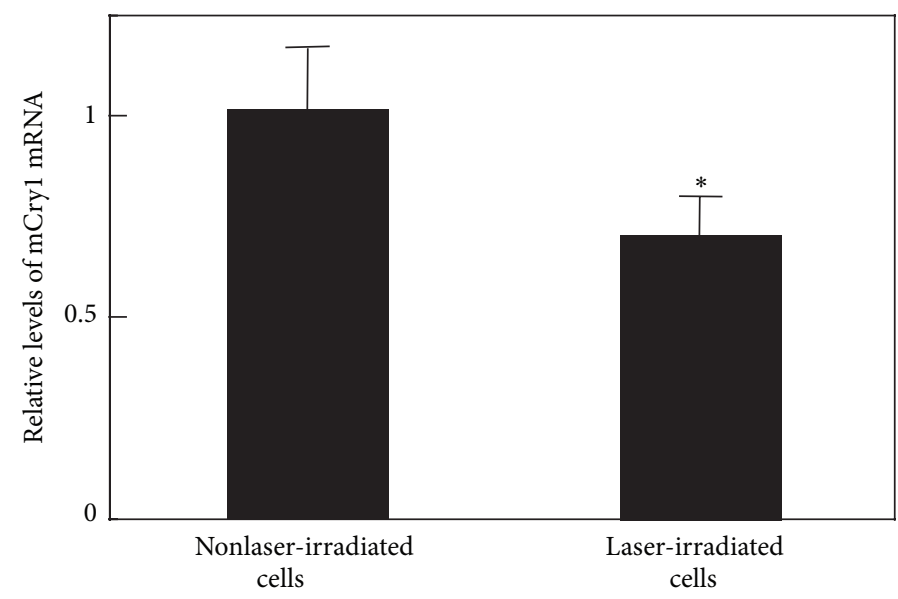

(b)

FIGURE 2: (a) Subcellular location of CRY1 proteins in MSCs after laser irradiation $\left(200 \mathrm{~mW} / \mathrm{cm}^{2}\right)$. Cells were double-labeled with DAPI (blue) and CRY1 (red). CRY1 localized to the cytoplasm prior to laser irradiation (A). However, after laser irradiation, CRY1 translocated to the nucleus (B) (scale bars: $50 \mu \mathrm{m}$ ). (b) mRNA levels of Cryl in MSCs $24 \mathrm{~h}$ after laser irradiation $\left(200 \mathrm{~mW} / \mathrm{cm}^{2}\right)$ and in nonirradiated cells. Samples were normalized to mRsp18. The mRNA levels of Cryl decreased after blue laser irradiation relative to nonirradiated cells $\left({ }^{*} P<0.01\right.$, indicating significant difference between the relative mRNA levels of laser-irradiated MSCs and controls) [3].

\section{Conflict of Interests}

The authors declare that there is no conflict of interests regarding the publication of this paper.

\section{Acknowledgment}

This review article was supported by KAKENHI Grant no. 25713009 from Japan Society for the Promotion of Science (JSPS).

\section{References}

[1] V. I. Sikavitsas, J. S. Temenoff, and A. G. Mikos, "Biomaterials and bone mechanotransduction," Biomaterials, vol. 22, no. 19, pp. 2581-2593, 2001.

[2] T. Kushibiki and K. Awazu, "Controlling osteogenesis and adipogenesis of mesenchymal stromal cells by regulating a circadian clock protein with laser irradiation," International Journal of Medical Sciences, vol. 5, no. 6, pp. 319-326, 2008.

[3] T. Kushibiki and K. Awazu, "Blue laser irradiation enhances extracellular calcification of primary mesenchymal stem cells," Photomedicine and Laser Surgery, vol. 27, no. 3, pp. 493-498, 2009.

[4] T. Kushibiki, T. Tajiri, Y. Ninomiya, and K. Awazu, "Chondrogenic mRNA expression in prechondrogenic cells after blue laser irradiation," Journal of Photochemistry and Photobiology B: Biology, vol. 98, no. 3, pp. 211-215, 2010.

[5] T. H. Maiman, "Stimulated optical radiation in Ruby," Nature, vol. 187, no. 4736, pp. 493-494, 1960.

[6] K. A. Khatri, D. L. Mahoney, and M. J. McCartney, "Laser scar revision: a review," Journal of Cosmetic and Laser Therapy, vol. 13, no. 2, pp. 54-62, 2011.

[7] S. H. Chung and E. Mazur, "Surgical applications of femtosecond lasers," Journal of Biophotonics, vol. 2, no. 10, pp. 557-572, 2009. 
[8] Z. Zhao and F. Wu, "Minimally-invasive thermal ablation of early-stage breast cancer: a systemic review," European Journal of Surgical Oncology, vol. 36, no. 12, pp. 1149-1155, 2010.

[9] B. Siribumrungwong, P. Noorit, C. Wilasrusmee, J. Attia, and A. Thakkinstian, "A systematic review and meta-analysis of randomised controlled trials comparing endovenous ablation and surgical intervention in patients with varicose vein," European Journal of Vascular and Endovascular Surgery, vol. 44, no. 2, pp. 214-223, 2012.

[10] M. E. Vuylsteke and S. R. Mordon, "Endovenous laser ablation: a review of mechanisms of action," Annals of Vascular Surgery, vol. 26, no. 3, pp. 424-433, 2012.

[11] A. Vogel and V. Venugopalan, "Mechanisms of pulsed laser ablation of biological tissues," Chemical Reviews, vol. 103, no. 2, pp. 577-644, 2003.

[12] A. Casas, G. Di Venosa, T. Hasan, and A. Batlle, "Mechanisms of resistance to photodynamic therapy," Current Medicinal Chemistry, vol. 18, no. 16, pp. 2486-2515, 2011.

[13] S. Anand, B. J. Ortel, S. P. Pereira, T. Hasan, and E. V. Maytin, "Biomodulatory approaches to photodynamic therapy for solid tumors," Cancer Letters, vol. 326, no. 1, pp. 8-16, 2012.

[14] E. Mester, B. Szende, and P. Gärtner, "The effect of laser beams on the growth of hair in mice," Radiobiologia, Radiotherapia, vol. 9, no. 5, pp. 621-626, 1968.

[15] R. Roelandts, "The history of phototherapy: something new under the sun?" Journal of the American Academy of Dermatology, vol. 46, no. 6, pp. 926-930, 2002.

[16] E. Mester, T. Spiry, B. Szende, and J. G. Tota, "Effect of laser rays on wound healing," The American Journal of Surgery, vol. 122, no. 4, pp. 532-535, 1971.

[17] J. P. da Silva, M. A. da Silva, A. P. F. Almeida, I. Lombardi Junior, and A. P. Matos, "Laser therapy in the tissue repair process: a literature review," Photomedicine and Laser Surgery, vol. 28, no. 1, pp. 17-21, 2010.

[18] W. Posten, D. A. Wrone, J. S. Dover, K. A. Arndt, S. Silapunt, and M. Alam, "Low-level laser therapy for wound healing: mechanism and efficacy," Dermatologic Surgery, vol. 31, no. 3, pp. 334-340, 2005.

[19] P. V. Peplow and G. D. Baxter, "Gene expression and release of growth factors during delayed wound healing: a review of studies in diabetic animals and possible combined laser phototherapy and growth factor treatment to enhance healing," Photomedicine and Laser Surgery, vol. 30, no. 11, pp. 617-636, 2012.

[20] P. V. Peplow, T.-Y. Chung, and G. D. Baxter, "Photodynamic modulation of wound healing: a review of human and animal studies," Photomedicine and Laser Surgery, vol. 30, no. 3, pp. 118148, 2012.

[21] H. S. Yu, K. L. Chang, C. L. Yu, J. W. Chen, and G. S. Chen, "Lowenergy helium-neon laser irradiation stimulates interleukinlalpha and interleukin- 8 release from cultured human keratinocytes," Journal of Investigative Dermatology, vol. 107, no. 4, pp. 593-596, 1996.

[22] N. Kipshidze, V. Nikolaychik, M. H. Keelan et al., "Low-power helium: neon laser irradiation enhances production of vascular endothelial growth factor and promotes growth of endothelial cells in vitro," Lasers in Surgery and Medicine, vol. 28, no. 4, pp. 355-364, 2001.

[23] A. Khanna, L. R. Shankar, M. H. Keelan et al., "Augmentation of the expression of proangiogenic genes in cardiomyocytes with low dose laser irradiation In vitro," Cardiovascular Radiation Medicine, vol. 1, no. 3, pp. 265-269, 1999.
[24] F. Correa, R. A. Lopes Martins, J. C. Correa, V. V. Iversen, J. Joenson, and J. M. Bjordal, "Low-level laser therapy (GaAs lambda $=904 \mathrm{~nm}$ ) reduces inflammatory cell migration in mice with lipopolysaccharide-induced peritonitis," Photomedicine and laser surgery, vol. 25, no. 4, pp. 245-249, 2007.

[25] E. S. Boschi, C. E. Leite, V. C. Saciura et al., "Anti-inflammatory effects of low-level laser therapy $(660 \mathrm{~nm})$ in the early phase in carrageenan-induced pleurisy in rat," Lasers in Surgery and Medicine, vol. 40, no. 7, pp. 500-508, 2008.

[26] F. Aimbire, R. Albertini, M. T. T. Pacheco et al., "Low-level laser therapy induces dose-dependent reduction of TNF $\alpha$ levels in acute inflammation," Photomedicine and Laser Surgery, vol. 24, no. 1, pp. 33-37, 2006.

[27] F. Aimbire, A. P. Ligeiro De Oliveira, R. Albertini et al., "Low level laser therapy (LLLT) decreases pulmonary microvascular leakage, neutrophil influx and IL-1 $\beta$ levels in airway and lung from rat subjected to LPS-induced inflammation," Inflammation, vol. 31, no. 3, pp. 189-197, 2008.

[28] F. Aimbire, F. V. Santos, R. Albertini, H. C. Castro-Faria-Neto, J. Mittmann, and C. Pacheco-Soares, "Low-level laser therapy decreases levels of lung neutrophils anti-apoptotic factors by a $\mathrm{NF}-\kappa \mathrm{B}$ dependent mechanism," International Immunopharmacology, vol. 8, no. 4, pp. 603-605, 2008.

[29] R. Albertini, F. Aimbire, A. B. Villaverde, J. A. Silva Jr., and M. S. Costa, "COX-2 mRNA expression decreases in the subplantar muscle of rat paw subjected to carrageenan-induced inflammation after low level laser therapy," Inflammation Research, vol. 56, no. 6, pp. 228-229, 2007.

[30] R. Albertini, F. S. C. Aimbire, F. I. Correa et al., "Effects of different protocol doses of low power gallium-aluminumarsenate (Ga-Al-As) laser radiation $(650 \mathrm{~nm})$ on carrageenan induced rat paw ooedema," Journal of Photochemistry and Photobiology B: Biology, vol. 74, no. 2-3, pp. 101-107, 2004.

[31] R. Albertini, A. B. Villaverde, F. Aimbire et al., "Cytokine mRNA expression is decreased in the subplantar muscle of rat paw subjected to carrageenan-induced inflammation after low-level laser therapy," Photomedicine and Laser Surgery, vol. 26, no. 1, pp. 19-24, 2008.

[32] R. Albertini, A. B. Villaverde, F. Aimbire et al., "Antiinflammatory effects of low-level laser therapy (LLLT) with two different red wavelengths ( $660 \mathrm{~nm}$ and $684 \mathrm{~nm}$ ) in carrageenaninduced rat paw edema," Journal of Photochemistry and Photobiology B: Biology, vol. 89, no. 1, pp. 50-55, 2007.

[33] A. C. A. Alves, R. D. P. Vieira, E. C. P. Leal-Junior et al., "Effect of low-level laser therapy on the expression of inflammatory mediators and on neutrophils and macrophages in acute joint inflammation," Arthritis Research \& Therapy, vol. 15, no. 5, article R116, 2013.

[34] F. Bortone, H. A. Santos, R. Albertini, J. B. Pesquero, M. S. Costa, and J. A. Silva Jr., "Low level laser therapy modulates kinin receptors mRNA expression in the subplantar muscle of rat paw subjected to carrageenan-induced inflammation," International Immunopharmacology, vol. 8, no. 2, pp. 206-210, 2008.

[35] H. L. Casalechi, E. C. P. Leal-Junior, M. Xavier et al., "Low-level laser therapy in experimental model of collagenase-induced tendinitis in rats: Effects in acute and chronic inflammatory phases," Lasers in Medical Science, vol. 28, no. 3, pp. 989-995, 2013.

[36] P. de Almeida, R. Á. B. Lopes-Martins, S. S. Tomazoni et al., "Low-level laser therapy and sodium diclofenac in acute inflammatory response induced by skeletal muscle trauma: effects in muscle morphology and mRNA gene expression of 
inflammatory markers," Photochemistry and Photobiology, vol. 89, no. 2, pp. 501-507, 2013.

[37] F. M. de Lima, R. Albertini, Y. Dantas et al., "Low-level laser therapy restores the oxidative stress balance in acute lung injury induced by gut ischemia and reperfusion," Photochemistry and Photobiology, vol. 89, no. 1, pp. 179-188, 2013.

[38] F. M. De Lima, A. B. Villaverde, R. Albertini et al., "Dual Effect of low-level laser therapy (LLLT) on the acute lung inflammation induced by intestinal ischemia and reperfusion: action on anti- and pro-inflammatory cytokines," Lasers in Surgery and Medicine, vol. 43, no. 5, pp. 410-420, 2011.

[39] F. M. de Lima, A. B. Villaverde, R. Albertini, A. P. L. de Oliveira, H. C. C. F. Neto, and F. Aimbire, "Low-level laser therapy associated to $\mathrm{N}$-acetylcysteine lowers macrophage inflammatory protein-2 (MIP-2) mRNA expression and generation of intracellular reactive oxygen species in alveolar macrophages," Photomedicine and Laser Surgery, vol. 28, no. 6, pp. 763-771, 2010.

[40] E. M. S. Laraia, I. S. Silva, D. M. Pereira et al., "Effect of lowlevel laser therapy $(660 \mathrm{~nm})$ on acute inflammation induced by tenotomy of achilles tendon in rats," Photochemistry and Photobiology, vol. 88, no. 6, pp. 1546-1550, 2012.

[41] R. A. B. Lopes-Martins, R. Albertini, P. S. L. Lopes Martins, J. M. Bjordal, and H. C. C. Faria Neto, "Spontaneous effects of low-level laser therapy $(650 \mathrm{~nm})$ in acute inflammatory mouse pleurisy induced by carrageenan," Photomedicine and Laser Surgery, vol. 23, no. 4, pp. 377-381, 2005.

[42] F. Mafra de Lima, M. S. Costa, R. Albertini, J. A. Silva Jr., and F. Aimbire, "Low level laser therapy (LLLT): attenuation of cholinergic hyperreactivity, $\beta 2$-adrenergic hyporesponsiveness and TNF- $\alpha$ mRNA expression in rat bronchi segments in E. coli lipopolysaccharide-induced airway inflammation by a NF- $\kappa \mathrm{B}$ dependent mechanism," Lasers in Surgery and Medicine, vol. 41, no. 1, pp. 68-74, 2009.

[43] F. Mafra de Lima, K. T. Naves, A. H. Machado, R. Albertini, A. B. Villaverde, and F. Aimbire, "Lung inflammation and endothelial cell damage are decreased after treatment with phototherapy $(\mathrm{PhT})$ in a model of acute lung injury induced by Escherichia coli lipopolysaccharide in the rat," Cell Biology International, vol. 33, no. 12, pp. 1212-1221, 2009.

[44] F. Mafra de Lima, A. B. Villaverde, M. A. Salgado et al., "Low intensity laser therapy (LILT) in vivo acts on the neutrophils recruitment and chemokines/cytokines levels in a model of acute pulmonary inflammation induced by aerosol of lipopolysaccharide from Escherichia coli in rat," Journal of Photochemistry and Photobiology B: Biology, vol. 101, no. 3, pp. 271-278, 2010.

[45] D. Pires, M. Xavier, T. Araújo, J. A. Silva Jr., F. Aimbire, and R. Albertini, "Low-level laser therapy (LLLT; $780 \mathrm{~nm}$ ) acts differently on mRNA expression of anti- and pro-inflammatory mediators in an experimental model of collagenase-induced tendinitis in rat," Lasers in Medical Science, vol. 26, no. 1, pp. 85-94, 2011.

[46] M. Xavier, D. R. David, R. A. De Souza et al., "Antiinflammatory effects of low-level light emitting diode therapy on Achilles tendinitis in rats," Lasers in Surgery and Medicine, vol. 42, no. 6, pp. 553-558, 2010.

[47] Y. Ozawa, N. Shimizu, G. Kariya, and Y. Abiko, "Low-energy laser irradiation stimulates bone nodule formation at early stages of cell culture in rat calvarial cells," Bone, vol. 22, no. 4, pp. 347-354, 1998.
[48] A. N. Silva Júnior, A. L. B. Pinheiro, M. G. Oliveira, R. Weismann, L. M. Pedreira Ramalho, and R. Amadei Nicolau, "Computerized morphometric assessment of the effect of lowlevel laser therapy on bone repair: an experimental animal study," Journal of Clinical Laser Medicine and Surgery, vol. 20, no. 2, pp. 83-87, 2002.

[49] N. Shimizu, K. Mayahara, T. Kiyosaki, A. Yamaguchi, Y. Ozawa, and Y. Abiko, "Low-intensity laser irradiation stimulates bone nodule formation via insulin-like growth factor-I expression in rat calvarial cells," Lasers in Surgery and Medicine, vol. 39, no. 6, pp. 551-559, 2007.

[50] V. Aleksic, A. Aoki, K. Iwasaki et al., "Low-level Er: YAG laser irradiation enhances osteoblast proliferation through activation of MAPK/ERK," Lasers in Medical Science, vol. 25, no. 4, pp. 559-569, 2010.

[51] S. Hirata, C. Kitamura, H. Fukushima et al., "Low-level laser irradiation enhances BMP-induced osteoblast differentiation by stimulating the BMP/Smad signaling pathway," Journal of Cellular Biochemistry, vol. 111, no. 6, pp. 1445-1452, 2010.

[52] D. Gigo-Benato, T. L. Russo, E. H. Tanaka, L. Assis, T. F. Salvini, and N. A. Parizotto, "Effects of 660 and $780 \mathrm{~nm}$ low-level laser therapy on neuromuscular recovery after crush injury in rat sciatic nerve," Lasers in Surgery and Medicine, vol. 42, no. 9, pp. 673-682, 2010.

[53] C.-C. Shen, Y.-C. Yang, T.-B. Huang, S.-C. Chan, and B.-S. Liu, "Neural regeneration in a novel nerve conduit across a large gap of the transected sciatic nerve in rats with low-level laser phototherapy," Journal of Biomedical Materials Research Part: A, vol. 101, no. 10, pp. 2763-2777, 2013.

[54] D. Gigo-Benato, S. Geuna, and S. Rochkind, "Phototherapy for enhancing peripheral nerve repair: a review of the literature," Muscle and Nerve, vol. 31, no. 6, pp. 694-701, 2005.

[55] J. J. Anders, S. Geuna, and S. Rochkind, "Phototherapy promotes regeneration and functional recovery of injured peripheral nerve," Neurological Research, vol. 26, no. 2, pp. 233-239, 2004.

[56] M. Bayat, E. Ansari, N. Gholami, and A. Bayat, "Effect of lowlevel helium-neon laser therapy on histological and ultrastructural features of immobilized rabbit articular cartilage," Journal of Photochemistry and Photobiology B: Biology, vol. 87, no. 2, pp. 81-87, 2007.

[57] D. Avni, S. Levkovitz, L. Maltz, and U. Oron, "Protection of skeletal muscles from ischemic injury: low-level laser therapy increases antioxidant activity," Photomedicine and Laser Surgery, vol. 23, no. 3, pp. 273-277, 2005.

[58] R. Á. B. Lopes-Martins, R. L. Marcos, P. S. Leonardo et al., "Effect of low-level laser (Ga-Al-As $655 \mathrm{~nm}$ ) on skeletal muscle fatigue induced by electrical stimulation in rats," Journal of Applied Physiology, vol. 101, no. 1, pp. 283-288, 2006.

[59] E. C. P. Leal, R. Á. B. Lopes-Martins, F. Dalan et al., "Effect of 655-nm low-level laser therapy on exercise-induced skeletal muscle fatigue in humans," Photomedicine and Laser Surgery, vol. 26, no. 5, pp. 419-424, 2008.

[60] K. M. AlGhamdi, A. Kumar, and N. A. Moussa, "Low-level laser therapy: a useful technique for enhancing the proliferation of various cultured cells," Lasers in Medical Science, vol. 27, no. 1, pp. 237-249, 2012.

[61] X. Gao and D. Xing, "Molecular mechanisms of cell proliferation induced by low power laser irradiation," Journal of Biomedical Science, vol. 16, no. 1, article 4, 2009.

[62] J. Tafur, E. P. A. van Wijk, R. van Wijk, and P. J. Mills, "Biophoton detection and low-intensity light therapy: a potential clinical 
partnership," Photomedicine and laser surgery, vol. 28, no. 1, pp. 23-30, 2010.

[63] L. Gavish, L. S. Perez, P. Reissman, and S. D. Gertz, "Irradiation with $780 \mathrm{~nm}$ diode laser attenuates inflammatory cytokines but upregulates nitric oxide in lipopolysaccharide-stimulated macrophages: implications for the prevention of aneurysm progression," Lasers in Surgery and Medicine, vol. 40, no. 5, pp. 371-378, 2008.

[64] A. Lindgård, L. M. Hultén, L. Svensson, and B. Soussi, "Irradiation at $634 \mathrm{~nm}$ releases nitric oxide from human monocytes," Lasers in Medical Science, vol. 22, no. 1, pp. 30-36, 2007.

[65] Y. Moriyama, E. H. Moriyama, K. Blackmore, M. K. Akens, and L. Lilge, "In vivo study of the inflammatory modulating effects of low-level laser therapy on iNOS expression using bioluminescence imaging," Photochemistry and Photobiology, vol. 81, no. 6, pp. 1351-1355, 2005.

[66] Y. Moriyama, J. Nguyen, M. Akens, E. H. Moriyama, and L. Lilge, "In vivo effects of low level laser therapy on inducible nitric oxide synthase," Lasers in Surgery and Medicine, vol. 41, no. 3, pp. 227-231, 2009.

[67] H. Tuby, L. Maltz, and U. Oron, "Modulations of VEGF and iNOS in the rat heart by low level laser therapy are associated with cardioprotection and enhanced angiogenesis," Lasers in Surgery and Medicine, vol. 38, no. 7, pp. 682-688, 2006.

[68] T. Y. Fukuda, M. M. Tanji, S. R. Silva, M. N. Sato, and H. Plapler, "Infrared low-level diode laser on inflammatory process modulation in mice: pro- and anti-inflammatory cytokines," Lasers in Medical Science, vol. 28, no. 5, pp. 1305-1313, 2013.

[69] R. G. Oliveira, A. P. Ferreira, A. J. Côrtes, B. J. V. Aarestrup, L. C. Andrade, and F. M. Aarestrup, "Low-level laser reduces the production of TNF- $\alpha$, IFN- $\gamma$, and IL-10 induced by OVA," Lasers in Medical Science, vol. 28, no. 6, pp. 1519-1525, 2013.

[70] M. Yamaura, M. Yao, I. Yaroslavsky, R. Cohen, M. Smotrich, and I. E. Kochevar, "Low level light effects on inflammatory cytokine production by rheumatoid arthritis synoviocytes," Lasers in Surgery and Medicine, vol. 41, no. 4, pp. 282-290, 2009.

[71] S. M. Safavi, B. Kazemi, M. Esmaeili, A. Fallah, A. Modarresi, and M. Mir, "Effects of low-level He-Ne laser irradiation on the gene expression of IL- $1 \beta$, TNF- $\alpha$, IFN- $\gamma$, TGF- $\beta$, bFGF, and PDGF in rat's gingiva," Lasers in Medical Science, vol. 23, no. 3 , pp. 331-335, 2008.

[72] H. Shiba, H. Tsuda, M. Kajiya et al., "Neodymium-doped yttrium-aluminium-garnet laser irradiation abolishes the increase in interleukin-6 levels caused by peptidoglycan through the p38 mitogen-activated protein kinase pathway in human pulp cells," Journal of Endodontics, vol. 35, no. 3, pp. 373-376, 2009.

[73] N. N. Houreld, P. R. Sekhejane, and H. Abrahamse, "Irradiation at $830 \mathrm{~nm}$ stimulates nitric oxide production and inhibits proinflammatory cytokines in diabetic wounded fibroblast cells," Lasers in Surgery and Medicine, vol. 42, no. 6, pp. 494-502, 2010.

[74] M. Šimunović-Šoškić, S. Pezelj-Ribarić, G. Brumini, I. Glažar, R. Gržić, and I. Miletić, "Salivary levels of TNF-alpha and IL6 in patients with denture stomatitis before and after laser phototherapy," Photomedicine and Laser Surgery, vol. 28, no. 2, pp. 189-193, 2010.

[75] T. Fushimi, S. Inui, T. Nakajima, M. Ogasawara, K. Hosokawa, and S. Itami, "Green light emitting diodes accelerate wound healing: characterization of the effect and its molecular basis in vitro and in vivo," Wound Repair and Regeneration, vol. 20, no. 2, pp. 226-235, 2012.
[76] I. Saygun, S. Karacay, M. Serdar, A. U. Ural, M. Sencimen, and B. Kurtis, "Effects of laser irradiation on the release of basic fibroblast growth factor (bFGF), insulin like growth factor-1 (IGF-1), and receptor of IGF-1 (IGFBP3) from gingival fibroblasts," Lasers in Medical Science, vol. 23, no. 2, pp. 211-215, 2008.

[77] F. Schwartz, C. Brodie, E. Appel, G. Kazimirsky, and A. Shainberg, "Effect of helium/neon laser irradiation on nerve growth factor synthesis and secretion in skeletal muscle cultures," Journal of Photochemistry and Photobiology B: Biology, vol. 66, no. 3, pp. 195-200, 2002.

[78] W. Yu, J. O. Naim, and R. J. Lanzafame, "The effect of laser irradiation on the release of bFGF from 3T3 fibroblasts," Photochemistry and Photobiology, vol. 59, no. 2, pp. 167-170, 1994.

[79] W. P. Hu, J. J. Wang, C. L. Yu, C. C. E. Lan, G. S. Chen, and H. S. $\mathrm{Yu}$, "Helium-neon laser irradiation stimulates cell proliferation through photostimulatory effects in mitochondria," Journal of Investigative Dermatology, vol. 127, no. 8, pp. 2048-2057, 2007.

[80] C.-C. E. Lan, C.-S. Wu, M.-H. Chiou, T.-Y. Chiang, and H.S. Yu, "Low-energy helium-neon laser induces melanocyte proliferation via interaction with type IV collagen: visible light as a therapeutic option for vitiligo," British Journal of Dermatology, vol. 161, no. 2, pp. 273-280, 2009.

[81] S. Wu, D. Xing, X. Gao, and W. R. Chen, "High fluence lowpower laser irradiation induces mitochondrial permeability transition mediated by reactive oxygen species," Journal of Cellular Physiology, vol. 218, no. 3, pp. 603-611, 2009.

[82] I. L. Zungu, D. Hawkins Evans, and H. Abrahamse, "Mitochondrial responses of normal and injured human skin fibroblasts following low level laser irradiation-an in vitro study," Photochemistry and Photobiology, vol. 85, no. 4, pp. 987-996, 2009.

[83] T. Karu, "Photobiology of low-power laser effects," Health Physics, vol. 56, no. 5, pp. 691-704, 1989.

[84] T. I. Karu, "Mitochondrial signaling in mammalian cells activated by red and near-IR radiation," Photochemistry and Photobiology, vol. 84, no. 5, pp. 1091-1099, 2008.

[85] O. Tiphlova and T. Karu, "Role of primary photoacceptors in low-power laser effects: action of $\mathrm{He}-\mathrm{Ne}$ laser radiation on bacteriophage T4-Escherichia coli interaction," Lasers in Surgery and Medicine, vol. 9, no. 1, pp. 67-69, 1989.

[86] L. Zhang, D. Xing, D. Zhu, and Q. Chen, "Low-power laser irradiation inhibiting Abeta25-35-induced PC12 cell apoptosis via PKC activation," Cellular Physiology and Biochemistry, vol. 22, no. 1-4, pp. 215-222, 2008.

[87] T. Kushibiki, T. Hirasawa, S. Okawa, and M. Ishihara, "Blue laser irradiation generates intracellular reactive oxygen species in various types of cells," Photomedicine and Laser Surgery, vol. 31, no. 3, pp. 95-104, 2013.

[88] A. Lipovsky, Y. Nitzan, and R. Lubart, "A possible mechanism for visible light-induced wound healing," Lasers in Surgery and Medicine, vol. 40, no. 7, pp. 509-514, 2008.

[89] N. Ignatieva, O. Zakharkina, I. Andreeva, E. Sobol, V. Kamensky, and V. Lunin, "Effects of laser irradiation on collagen organization in chemically induced degenerative annulus fibrosus of lumbar intervertebral disc," Lasers in Surgery and Medicine, vol. 40, no. 6, pp. 422-432, 2008.

[90] L. B. Silveira, R. A. Prates, M. D. Novelli et al., "Investigation of mast cells in human gingiva following low-intensity laser irradiation," Photomedicine and Laser Surgery, vol. 26, no. 4, pp. 315-321, 2008. 
[91] A. R. Coombe, C.-T. G. Ho, M. A. Darendeliler et al., "The effects of low level laser irradiation on osteoblastic cells," Orthodontics and Craniofacial Research, vol. 4, no. 1, pp. 3-14, 2001.

[92] J. C. Sutherland, "Biological effects of polychromatic light," Photochemistry and Photobiology, vol. 76, no. 2, pp. 164-170, 2002.

[93] T. I. Karu, L. V. Pyatibrat, S. F. Kolyakov, and N. I. Afanasyeva, "Absorption measurements of a cell monolayer relevant to phototherapy: reduction of cytochrome $c$ oxidase under near IR radiation," Journal of Photochemistry and Photobiology B: Biology, vol. 81, no. 2, pp. 98-106, 2005.

[94] M. T. T. Wong-Riley, H. L. Liang, J. T. Eells et al., "Photobiomodulation directly benefits primary neurons functionally inactivated by toxins: Role of cytochrome c oxidase," The Journal of Biological Chemistry, vol. 280, no. 6, pp. 4761-4771, 2005.

[95] D. Pastore, M. Greco, V. A. Petragallo, and S. Passarella, "Increase in $\leftarrow \mathrm{H}+/ \mathrm{e}$ - ratio of the cytochrome c oxidase reaction in mitochondria irradiated with Helium-Neon laser," Biochemistry and Molecular Biology International, vol. 34, no. 4, pp. 817826, 1994.

[96] D. Barolet, P. Duplay, H. Jacomy, and M. Auclair, "Importance of pulsing illumination parameters in low-level-light therapy," Journal of Biomedical Optics, vol. 15, no. 4, Article ID 048005, 2010.

[97] J. Chu, S. Wu, and D. Xing, "Survivin mediates self-protection through ROS/cdc25c/CDK1 signaling pathway during tumor cell apoptosis induced by high fluence low-power laser irradiation," Cancer Letters, vol. 297, no. 2, pp. 207-219, 2010.

[98] T. I. Karu, L. V. Pyatibrat, and N. I. Afanasyeva, "Cellular effects of low power laser therapy can be mediated by nitric oxide," Lasers in Surgery and Medicine, vol. 36, no. 4, pp. 307-314, 2005.

[99] C.-C. E. Lan, S.-B. Wu, C.-S. Wu et al., "Induction of primitive pigment cell differentiation by visible light (helium-neon laser): a photoacceptor-specific response not replicable by UVB irradiation," Journal of Molecular Medicine, vol. 90, no. 3, pp. 321-330, 2012.

[100] J. Lim, R. A. Sanders, A. C. Snyder, J. T. Eells, D. S. Henshel, and J. B. Watkins, "Effects of low-level light therapy on streptozotocin-induced diabetic kidney," Journal of Photochemistry and Photobiology B: Biology, vol. 99, no. 2, pp. 105-110, 2010.

[101] L. Santana-Blank, E. Rodríguez-Santana, and K. SantanaRodríguez, "Theoretic, experimental, clinical bases of the water oscillator hypothesis in near-infrared photobiomodulation," Photomedicine and Laser Surgery, vol. 28, no. 1, pp. S41-S52, 2010.

[102] P. C. L. Silveira, E. L. Streck, and R. A. Pinho, "Evaluation of mitochondrial respiratory chain activity in wound healing by low-level laser therapy," Journal of Photochemistry and Photobiology B: Biology, vol. 86, no. 3, pp. 279-282, 2007.

[103] Z.-H. Wu, Y. Zhou, J.-Y. Chen, and L.-W. Zhou, "Mitochondrial signaling for histamine releases in laser-irradiated RBL-2H3 mast cells," Lasers in Surgery and Medicine, vol. 42, no. 6, pp. 503-509, 2010.

[104] S. Verma, G. M. Watt, Z. Mai, and T. Hasan, "Strategies for enhanced photodynamic therapy effects," Photochemistry and Photobiology, vol. 83, no. 5, pp. 996-1005, 2007.

[105] V. Massey, "The chemical and biological versatility of riboflavin," Biochemical Society Transactions, vol. 28, no. 4, pp. 283-296, 2000.

[106] M. Eichler, R. Lavi, A. Shainberg, and R. Lubart, "Flavins are source of visible-light-induced free radical formation in cells," Lasers in Surgery and Medicine, vol. 37, no. 4, pp. 314-319, 2005.
[107] F. Q. Schafer and G. R. Buettner, "Redox environment of the cell as viewed through the redox state of the glutathione disulfide/glutathione couple," Free Radical Biology and Medicine, vol. 30, no. 11, pp. 1191-1212, 2001.

[108] P. Storz, "Mitochondrial ROS—radical detoxification, mediated by protein kinase D," Trends in Cell Biology, vol. 17, no. 1, pp. 13-18, 2007.

[109] H. Liu, R. Colavitti, I. I. Rovira, and T. Finkel, "Redoxdependent transcriptional regulation," Circulation Research, vol. 97, no. 10, pp. 967-974, 2005.

[110] K. Irani, Y. Xia, J. L. Zweier et al., "Mitogenic signaling mediated by oxidants in Ras-transformed fibroblasts," Science, vol. 275, no. 5306, pp. 1649-1652, 1997.

[111] R. Schreck and A. Baeuerle, "A role for oxygen radicals as second messengers," Trends in Cell Biology, vol. 1, no. 2-3, pp. 39-42, 1991.

[112] W. Dröge, "Free radicals in the physiological control of cell function," Physiological Reviews, vol. 82, no. 1, pp. 47-95, 2002.

[113] R. Lavi, A. Shainberg, H. Friedmann et al., "Low energy visible light induces reactive oxygen species generation and stimulates an increase of intracellular calcium concentration in cardiac cells," The Journal of Biological Chemistry, vol. 278, no. 42, pp. 40917-40922, 2003.

[114] V. Borutaite, A. Budriunaite, and G. C. Brown, "Reversal of nitric oxide-, peroxynitrite- and $S$-nitrosothiol-induced inhibition of mitochondrial respiration or complex I activity by light and thiols," Biochimica et Biophysica Acta: Bioenergetics, vol. 1459, no. 2-3, pp. 405-412, 2000.

[115] G. A. Guzzardella, M. Fini, P. Torricelli, G. Giavaresi, and R. Giardino, "Laser stimulation on bone defect healing: an in vitro study," Lasers in Medical Science, vol. 17, no. 3, pp. 216-220, 2002.

[116] M. C. P. Leung, S. C. L. Lo, F. K. W. Siu, and K.-F. So, "Treatment of experimentally induced transient cerebral ischemia with low energy laser inhibits nitric oxide synthase activity and upregulates the expression of transforming growth factor-beta 1," Lasers in Surgery and Medicine, vol. 31, no. 4, pp. 283-288, 2002.

[117] M. Eichler, R. Lavi, H. Friedmann, A. Shainberg, and R. Lubart, "Red light-induced redox reactions in cells observed with TEMPO," Photomedicine and Laser Surgery, vol. 25, no. 3, pp. 170-174, 2007.

[118] C. F. Rizzi, J. L. Mauriz, D. S. F. Corrêa et al., "Effects of low-level laser therapy (LLLT) on the nuclear factor (NF) $-\kappa \mathrm{B}$ signaling pathway in traumatized muscle," Lasers in Surgery and Medicine, vol. 38, no. 7, pp. 704-713, 2006.

[119] C. T. Taylor, "Mitochondria and cellular oxygen sensing in the HIF pathway," Biochemical Journal, vol. 409, no. 1, pp. 19-26, 2008.

[120] E. Shaulian and M. Karin, "AP-1 as a regulator of cell life and death,” Nature Cell Biology, vol. 4, no. 5, pp. E131-E136, 2002.

[121] S. Bergelson, R. Pinkus, and V. Daniel, "Intracellular glutathione levels regulate Fos/Jun induction and activation of glutathione S-transferase gene expression," Cancer Research, vol. 54, no. 1, pp. 36-40, 1994.

[122] D. M. Flaherty, M. M. Monick, A. B. Carter, M. W. Peterson, and G. W. Hunninghake, "Oxidant-mediated increases in redox factor-1 nuclear protein and activator protein-1 DNA binding in asbestos-treated macrophages," The Journal of Immunology, vol. 168, no. 11, pp. 5675-5681, 2002.

[123] C. Lee, J.-P. Etchegaray, F. R. A. Cagampang, A. S. I. Loudon, and S. M. Reppert, "Posttranslational mechanisms regulate the mammalian circadian clock," Cell, vol. 107, no. 7, pp. 855-867, 2001. 
[124] L. Fu, M. S. Patel, A. Bradley, E. F. Wagner, and G. Karsenty, “The molecular clock mediates leptin-regulated bone formation," Cell, vol. 122, no. 5, pp. 803-815, 2005.

[125] S. Kawasaki, S. Ebara, K. Nakayama, and K. Takaoka, “The E-box motif, recognized by tissue-specific nuclear factor(s), is important for BMP-4 gene expression in osteogenic cells," Biochemical and Biophysical Research Communications, vol. 263, no. 2, pp. 560-565, 1999.

[126] I.-S. Park, P.-S. Chung, and J. C. Ahn, "Enhanced angiogenic effect of adipose-derived stromal cell spheroid with low-level light therapy in hind limb ischemia mice," Biomaterials, vol. 35, no. 34, pp. 9280-9289, 2014.

[127] D. Farfara, H. Tuby, D. Trudler et al., "Low-level laser therapy ameliorates disease progression in a mouse model of Alzheimer's disease," Journal of Molecular Neuroscience, vol. 55, no. 2, pp. :430-436, 2015.

[128] C.-C. Yang, J. Wang, S.-C. Chen, and Y.-L. Hsieh, "Synergistic effects of low-level laser and mesenchymal stem cells on functional recovery in rats with crushed sciatic nerves," Journal of Tissue Engineering and Regenerative Medicine, 2013.

[129] J.-Y. Wu, C.-H. Chen, C.-Z. Wang, M.-L. Ho, M.-L. Yeh, and Y.-H. Wang, "Low-power laser irradiation suppresses inflammatory response of human adipose-derived stem cells by modulating intracellular cyclic AMP level and NF-kappaB activity," PLoS ONE, vol. 8, no. 1, Article ID e54067, 2013.

[130] M. J. H. Nagata, C. S. Santinoni, N. M. Pola et al., "Bone marrow aspirate combined with low-level laser therapy: a new therapeutic approach to enhance bone healing," Journal of Photochemistry and Photobiology B: Biology, vol. 121, pp. 6-14, 2013.

[131] R. Manuguerra-Gagné, P. R. Boulos, A. Ammar et al., "Transplantation of mesenchymal stem cells promotes tissue regeneration in a glaucoma model through laser-induced paracrine factor secretion and progenitor cell recruitment," Stem Cells, vol. 31, no. 6, pp. 1136-1148, 2013.

[132] A. Lipovsky, U. Oron, A. Gedanken, and R. Lubart, "Lowlevel visible light (LLVL) irradiation promotes proliferation of mesenchymal stem cells," Lasers in Medical Science, vol. 28, no. 4, pp. 1113-1117, 2013.

[133] M. Giannelli, F. Chellini, C. Sassoli et al., "Photoactivation of bone marrow mesenchymal stromal cells with diode laser: effects and mechanisms of action," Journal of Cellular Physiology, vol. 228, no. 1, pp. 172-181, 2013.

[134] K. Choi, B.-J. Kang, H. Kim et al., "Low-level laser therapy promotes the osteogenic potential of adipose-derived mesenchymal stem cells seeded on an acellular dermal matrix," Journal of Biomedical Materials Research Part B: Applied Biomaterials, vol. 101, no. 6, pp. 919-928, 2013.

[135] B. S. Alexandrov, M. L. Phipps, L. B. Alexandrov et al., "Specificity and heterogeneity of terahertz radiation effect on gene expression in mouse mesenchymal stem cells," Scientific Reports, vol. 3, article 1184, 2013.

[136] B. S. Alexandrov, K. Ø. Rasmussen, A. R. Bishop et al., "Nonthermal effects of terahertz radiation on gene expression in mouse stem cells," Biomedical Optics Express, vol. 2, no. 9, pp. 2679-2689, 2011.

[137] J. Bock, Y. Fukuyo, S. Kang et al., "Mammalian stem cells reprogramming in response to terahertz radiation," PLOS ONE, vol. 5, no. 12, Article ID e15806, 2010.

[138] Y. H. Wu, J. Wang, D. X. Gong, H. Y. Gu, S. S. Hu, and H. Zhang, "Effects of low-level laser irradiation on mesenchymal stem cell proliferation: a microarray analysis," Lasers in Medical Science, vol. 27, no. 2, pp. 509-519, 2012.

[139] J.-Y. Wu, Y.-H. Wang, G.-J. Wang et al., "Low-power GaAlAs laser irradiation promotes the proliferation and osteogenic differentiation of stem cells via IGF1 and BMP2," PLoS ONE, vol. 7, no. 9, Article ID e44027, 2012.

[140] J. Wang, W. Huang, Y. Wu et al., "MicroRNA-193 proproliferation effects for bone mesenchymal stem cells after lowlevel laser irradiation treatment through inhibitor of growth family, member 5," Stem Cells and Development, vol. 21, no. 13, pp. 2508-2519, 2012.

[141] M. Soleimani, E. Abbasnia, M. Fathi, H. Sahraei, Y. Fathi, and G. Kaka, "The effects of low-level laser irradiation on differentiation and proliferation of human bone marrow mesenchymal stem cells into neurons and osteoblasts-an in vitro study," Lasers in Medical Science, vol. 27, no. 2, pp. 423-430, 2012.

[142] I. Saygun, N. Nizam, A. U. Ural, M. A. Serdar, F. Avcu, and T. F. Tözüm, "Low-level laser irradiation affects the release of basic fibroblast growth factor (bFGF), insulin-like growth factorI (IGF-I), and receptor of IGF-I (IGFBP3) from osteoblasts," Photomedicine and Laser Surgery, vol. 30, no. 3, pp. 149-154, 2012.

[143] H. Kim, K. Choi, O.-K. Kweon, and W. H. Kim, "Enhanced wound healing effect of canine adipose-derived mesenchymal stem cells with low-level laser therapy in athymic mice," Journal of Dermatological Science, vol. 68, no. 3, pp. 149-156, 2012.

[144] H. Abrahamse, "Regenerative medicine, stem cells, and lowlevel laser therapy: future directives," Photomedicine and Laser Surgery, vol. 30, no. 12, pp. 681-682, 2012.

[145] B. Mvula, T. Mathope, T. Moore, and H. Abrahamse, "The effect of low level laser irradiation on adult human adipose derived stem cells," Lasers in Medical Science, vol. 23, no. 3, pp. 277-282, 2008.

[146] B. Mvula, T. J. Moore, and H. Abrahamse, "Effect of low-level laser irradiation and epidermal growth factor on adult human adipose-derived stem cells," Lasers in Medical Science, vol. 25, no. 1, pp. 33-39, 2010.

[147] J. A. de Villiers, N. N. Houreld, and H. Abrahamse, "Influence of low intensity laser irradiation on isolated human adipose derived stem cells over 72 hours and their differentiation potential into smooth muscle cells using retinoic acid," Stem Cell Reviews and Reports, vol. 7, no. 4, pp. 869-882, 2011.

[148] L. Abramovitch-Gottlib, T. Gross, D. Naveh et al., "Low level laser irradiation stimulates osteogenic phenotype of mesenchymal stem cells seeded on a three-dimensional biomatrix," Lasers in Medical Science, vol. 20, no. 3-4, pp. 138-146, 2005. 

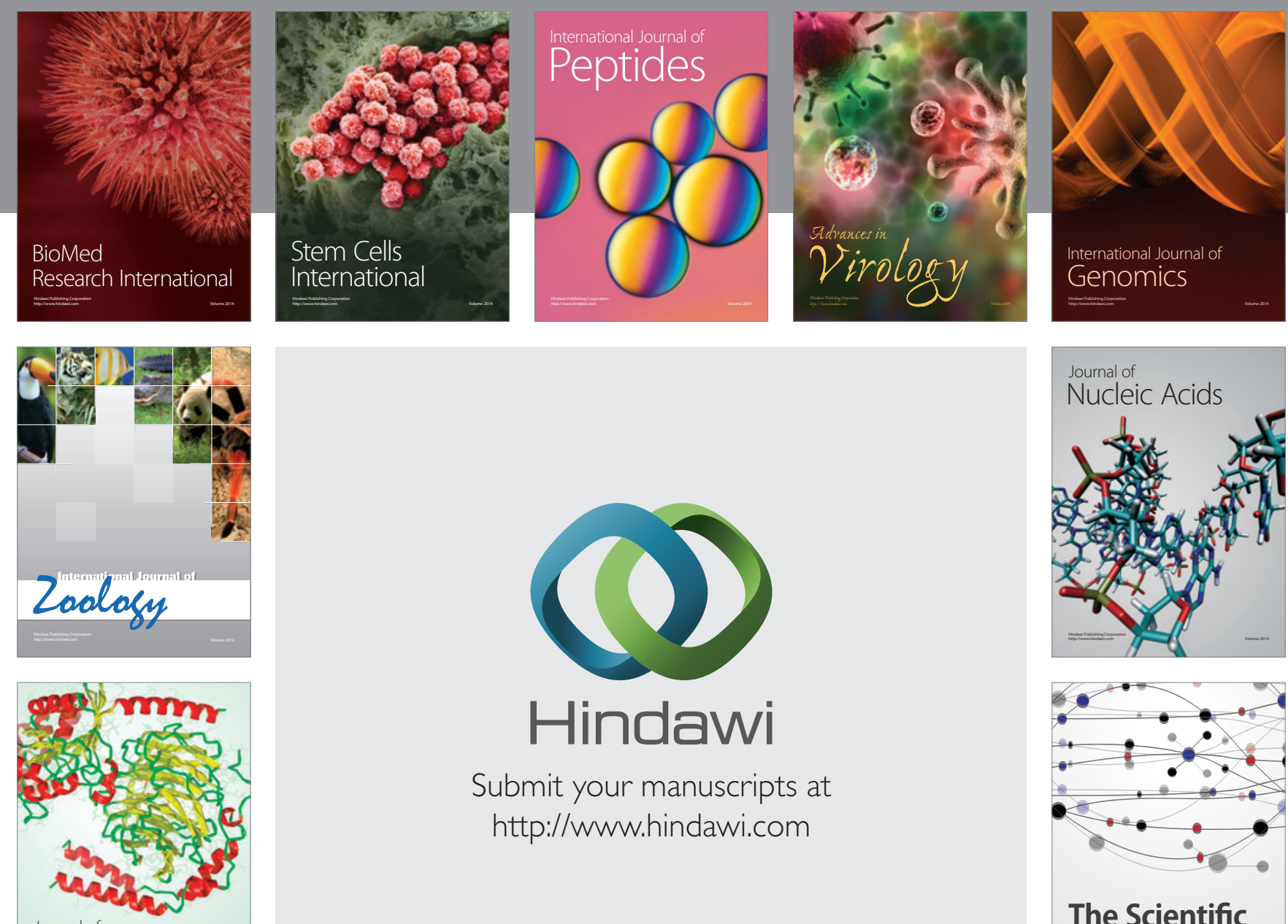

Submit your manuscripts at

http://www.hindawi.com

Journal of
Signal Transduction
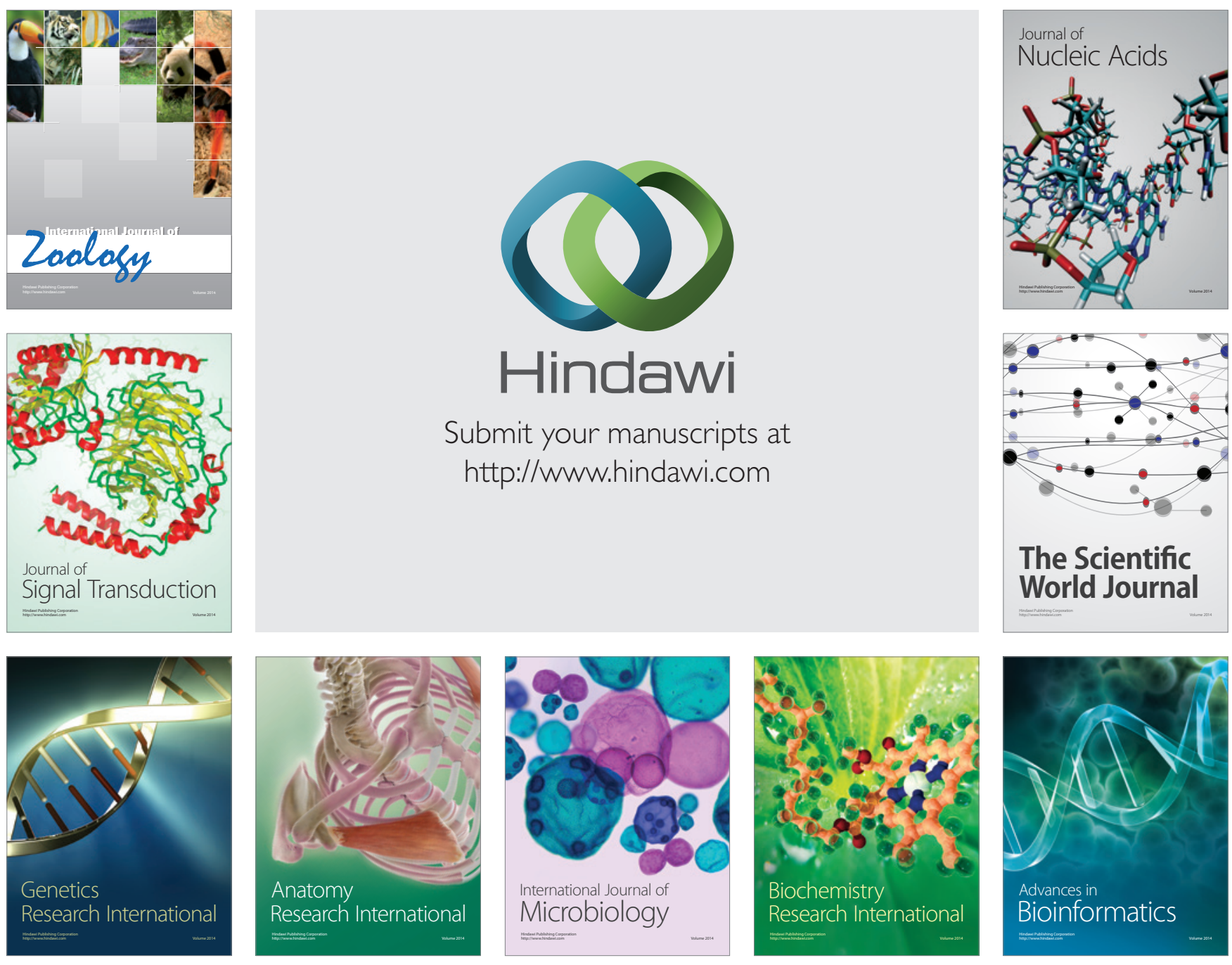

The Scientific World Journal
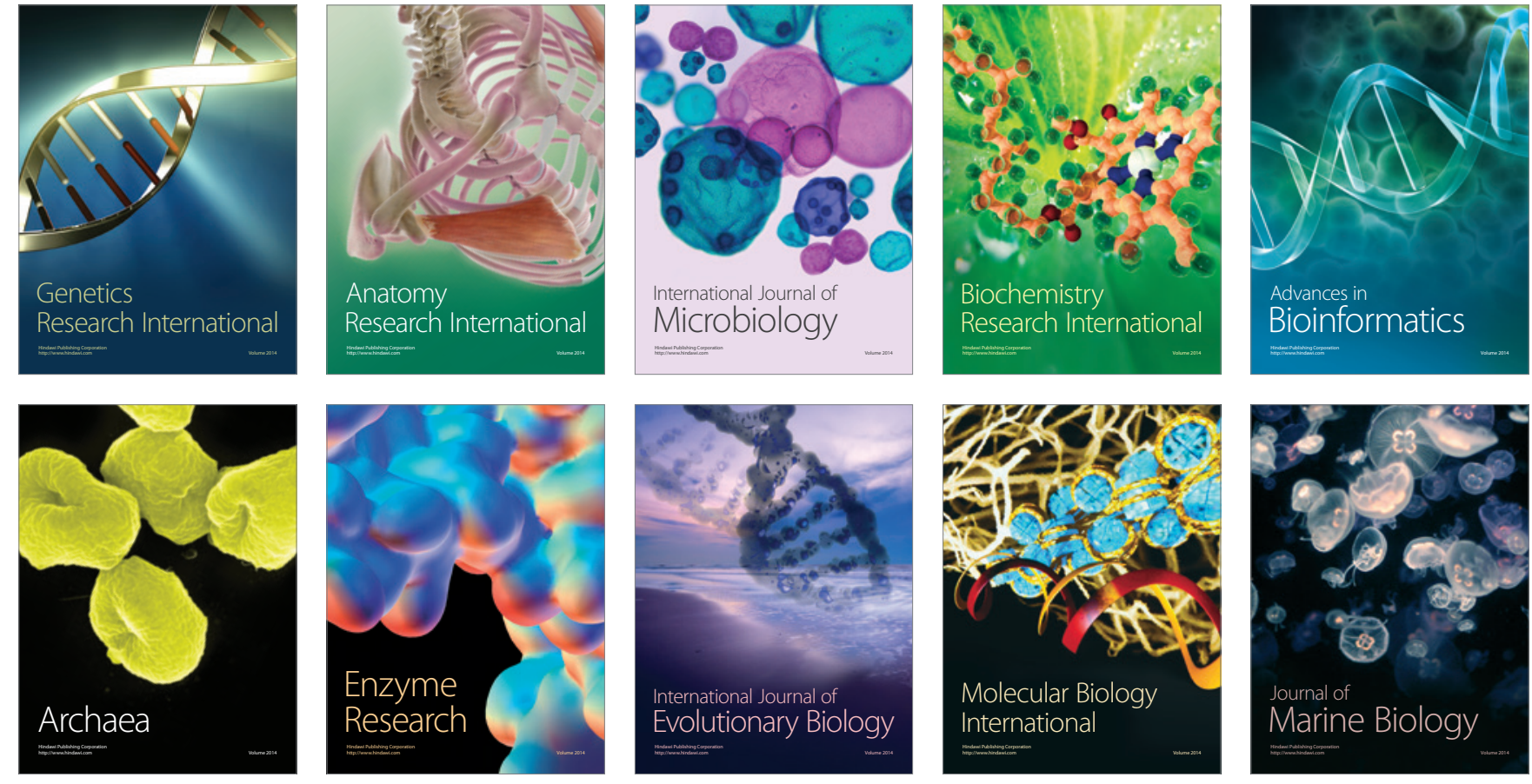